\title{
Dirty cookstoves pose enormous health risk
}

Previously published at www.cmaj.ca

$\mathrm{A}$ new global partnership is targeting a silent and often overlooked killer in the developing world: harmful smoke from the dirty cookstoves and open fires where women make their family meals.

Although the danger has received scant public attention, the World Health Organization (WHO) estimates that more than two million premature deaths annually are caused by exposure to smoke from traditional cookstoves and open fires, with women and children the most afflicted. That makes it one of the top five overall health risks in poor, developing countries, and the cause of twice as many deaths as malaria.

The toxic emissions are blamed for low birth weights, pneumonia in young children, and chronic obstructive pulmonary disease, emphysema, cardiovascular disease, lung cancer, cataracts and other health problems in adults. Half of all deaths among children under age five from acute lower respiratory infections are due to indoor air pollution from household solid fuels, according to WHO.

Now the new Global Alliance for Clean Cookstoves, a public-private partnership led by the UN Foundation, is being launched to address the problem. The alliance was announced by United States Secretary of State Hillary Rodham Clinton in September on the sidelines of the UN General Assembly meeting in New York City, New York.

"People have cooked over open fires and dirty stoves for all of human history," Clinton said in announcing the alliance. "But the simple fact is that they are slowly killing millions of people."

Getting people to switch to cleaner stoves that cost as little as $\$ 25$, she added, "could be as transformative as bed nets or vaccines."

"I know it may sound hard to believe, but by upgrading these stoves, millions of lives could be saved and improved."

Leslie Cordes, the UN Foundation's senior director for partnership development, says the negative effects of dirty cookstoves extend beyond health problems to include matters related to gen-

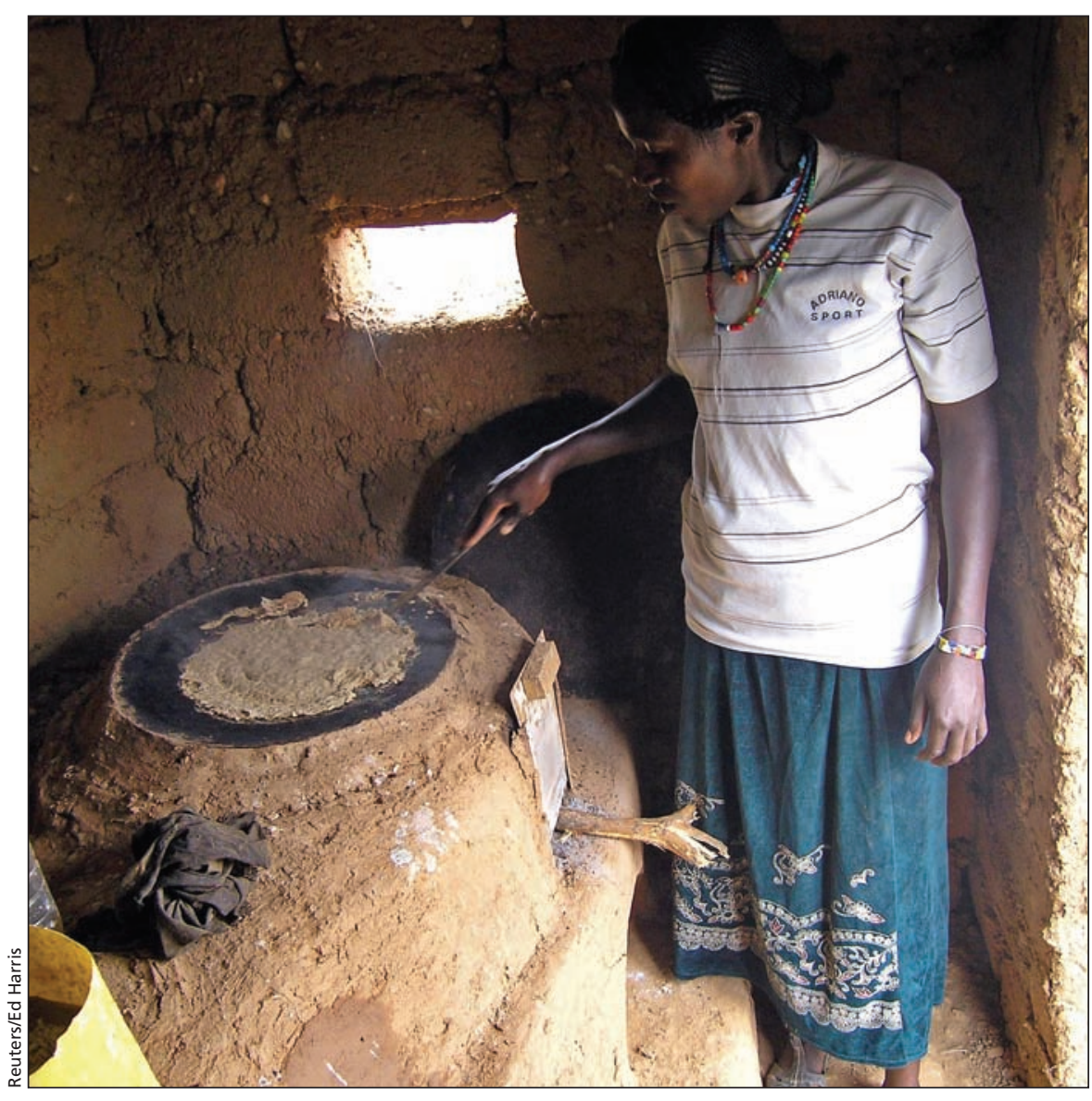

An Eritrean woman cooks on her improved mogogo stove, in Bimbilna Village, southwest Eritrea. The fuel-efficient stoves reduce consumption of firewood by $50 \%$, produce less smoke and eliminate the number of accidents caused by children falling into an open fire.

der, environmental protection and economic independence. Among them:

- Inefficient cookstoves emit pollutants such as methane and black carbon that contribute to climate change.

- Women and children spend hours collecting wood, dung or coal for fuel, time they could otherwise devote to school, crops or other more productive activities.

- In unstable areas such as refugee camps and conflict zones, women and girls risk being raped or subjected to other attacks when they venture out to gather wood.

- With roughly three billion people globally cooking their food by burning solids, the pressures on natural resources and habitat are huge, resulting in deforestation.

The alliance has established a "100 by 20 " goal, hoping to get 100 million homes to shift to cleaner stoves and fuels by 2020 .

The US government has committed US\$50 million over five years to the effort. Other donors have pledged US\$10 million and the ultimate goal is US\$250 million over 10 years. Among the partners in the alliance are the governments of Germany, Peru and Norway, international development organizations, nongovernmental organizations, and private companies including Morgan Stanley and Shell.

Dr. Maria Neira, WHO's director for Public Health and Environment, said the initiative "has the potential to halve childhood pneumonia mortality and dramatically improve the health of women through reducing lung cancer and disabling respiratory disease."

But supporters caution that addressing the problem will not be as simple 
as arranging mass distribution of cleaner stoves.

Catherine Bellamy, a Rome, Italybased policy officer with the UN World Food Programme, says more research is needed to fully understand the health effects of inhaling toxic smoke. In addition, global standards on stove efficiency and emissions are needed, she says, as well as a better understanding of what kinds of stoves will work best in different cultures.

Past clean cookstove efforts have failed due to a lack of knowledge about local cooking habits and inadequate training of those expected to use the stoves, she adds. For example, a stove that accommodates only a small pot wouldn't work for baking injera, the wide flat bread that is a staple in Ethiopia.

"Any time that you're talking about a cultural change in the way things are done, it's going to be complicated," Bellamy says. "You can't just drop a bunch of stoves and walk away."

In some cultures, new stoves might allow for more efficient use of existing fuels such as charcoal or firewood, Bellamy says. In others, she says, it might require switching to a different fuel such as ethanol.

In Kenya, where Masai women cook with wood, dung and crop residues, and fires are left smouldering day and night, installing simple smoke hoods on existing stoves cut down respirable particles by up to $80 \%$, according to the WHO.

Clinton said in her address that testing, monitoring and research are needed so that the stoves "will fit seamlessly into family cooking traditions while also offering a step up toward a better life." It's possible the new stoves could even use wasted heat to produce electricity to power fans, mobile phones and household lights, she said.

Cordes says awareness of the risk varies between countries, with some nations taking aggressive action while women in other areas are left unaware that their health problems are related to their cookstoves. Peru, India, China and Mexico all have clean cookstove programs, according to the alliance. Nancy Benac, Washington, DC

\section{Preonar 13 \\ Pneumococcal 13-valent Conjugate Voccine (Diphtheria CRM Prip Protein)}

\section{PREVNAR' 13 NOW AVALABLE}

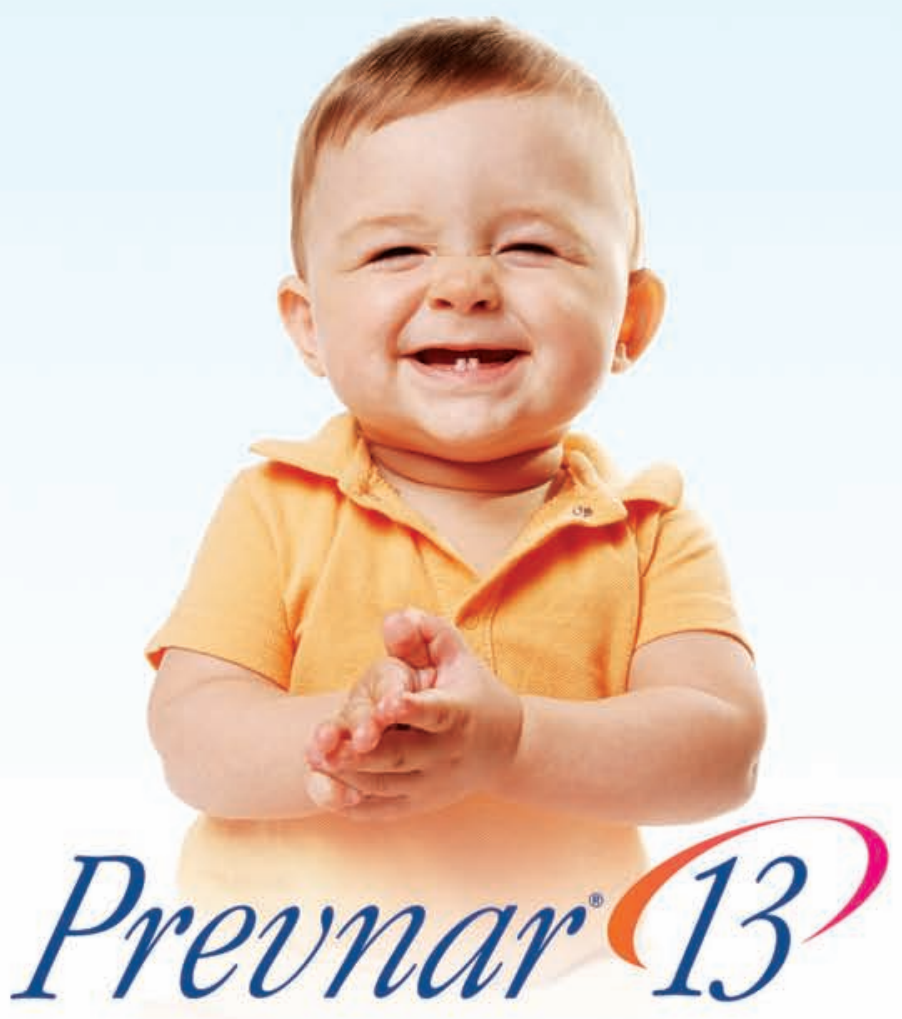

Prevnar 13 is indicated for the active immunization against Streptococcus pneumoniae serotypes $1,3,4,5,6 \mathrm{~A}, 6 \mathrm{~B}, 7 \mathrm{~F}, 9 \mathrm{~V}, 14,18 \mathrm{C}, 19 \mathrm{~A}, 19 \mathrm{~F}$ and $23 \mathrm{~F}$ causing invasive pneumococcal disease, including:

- Sepsis, meningitis, bacteraemic pneumonia, pleural empyema and bacteraemia

- Indicated for use in infants and children from 6 weeks through 5 years of age

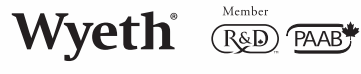

C) 2010 Wyeth Canada
Montréal, Canada H4R 1 J6 